\title{
JANUS ARCÚ KÁRTÉRÍTÉS - KÖZJOGI ELEMEK A KÁRTÉRÍTÁSI JOGBAN
}

\author{
Fézer Tamás ${ }^{1}$
}

A modern kártéritési jog olyan komplex funkcióval bir napjainkban, mely felveti a terület polgári jogon kivüli, keresztülfekvő jogterületként való értelmezését. A klasszikus reparáció (kompenzáció) - prevenció kettösén túlmutató célok nevelö, gyengébb fél védelmét szolgáló és gyakran repressziv elemekkel egészülnek ki. A diverz funkciókkal bíró terület modernkori változásai jellemzöen a társadalmi, gazdasági és technológiai fejlödés által generáltak, azonban tagadhatatlan a jogalkotó (az állam) egyre nagyobb mértékü beavatkozása a kártéritési jog klasszikus premisszáinak értelmezése terén. A számos speciális felelösségi alakzat léte, különösen az objektivv tárgyi felelösséget elötérbe helyezö esetek azt mutatják, hogy a kártéritési jog napjainkban jelentös mértékben inkább kockázatelosztó funkcióval bir, és a reparativ, kompenzációs szempontok sok esetben csupán másodlagosak. A jogpolitikai célok megtámogatására alkotott felelösségi alakzatok (pl. atomkárokért való felelösség, kötelezö védöoltások szövődményeiért való felelösség) vagy éppen a bizonyos szakmákkal szembeni gondossági követelményeket eltérö standardok mentén értékelö speciális felelösségi normák ${ }^{2}$ jól példázzák, miként próbál és számos esetben tud is hatni az állam egy gazdasági szektor belsö müködésére vagy éppen a társadalom moráljára.

\section{A felelősség hanyatlása és a jogalkotás beavatkozása}

A XX. században a felelősség hanyatlása, a vétkesség vizsgálatának háttérbe szorulása felerősítette a jogpolitikai elvárások és irányok szerepét a felelősségi jogban. Kiváló példa erre az angol jog 1933 utáni fejlődése. 1933-at megelőzően a gondatlan károkozások (negligenttorts) körében is lehetőség volt esküdtszéki tárgyalásra, így a bíró és az esküdtszék feladatai, döntési jogkörei megoszlottak: az esküdtszék a kötelezettségszegés, lényegében a jogellenesség, míg a bíró a vétkesség kérdésében hozott döntést. A bírói szerepkör erősítése iránti törekvésnek volt köszönhető az, hogy a vétkesség, a duty of care doktrína értelmezése központi kérdéssé vált az angol felelősségi jogban. 1933-ban azonban megszünt az esküdtszéki tárgyalás lehetősége a gondatlan károkozásokkal kapcsolatos perekben. A bírók már nem voltak érdekeltek abban, hogy a vétkességi koncepciót tovább fejlesszék, a kötelezettségszegés vizsgálata pedig klasszikusan nem az ő feladatuk volt. Mind a vétkesség, mind a kötelezettségszegés jogi értékelése elveszítette jelentőségét, és sokkal inkább morális, valamint elsősorban politikai, jogpolitikai kérdéssé vált. Ez az a tényező, mely véleményünk szerint a felelősségi jog belső differenciálódását elindította Angliában.

Akár normatív szempontból azonos felelősségi alakzathoz tartozó esetekben is rendkívül eltérően kerülhetnek értékelésre a felelősség előfeltételei. Az angol jogban például a vasúttársaságok esetében egy alapvetően jelentéktelen figyelmetlenség ${ }^{3}$ is elegendő a felelősségre vonáshoz, míg az orvos oldalán nagyobb fokú gondatlanság tanúsítását kell igazolni a kártérítésre kötelezés érdekében, holott mindkét esetkör teoretikusan azonos szabályok mentén kerül megítélésre. Tekintettel arra, hogy normatív oldalról nagyon nehezen definiálható mind a vétkesség, mind a jogellenesség a polgári jogi felelősség körében, így az aktuális társadalmi és jogpolitikai változásoknak talán ez a két felelősségtani premissza van leginkább kitéve.

\footnotetext{
${ }^{1}$ Fézer Tamás, habil. egyetemi docens, DE ÁJK

${ }^{2}$ Például a gazdasági társaságok vezető tisztségviselőinek felelőssége, egészségügyi szolgáltatók felelőssége a tájékoztatási kötelezettség megsértéséből eredő károkért.

${ }^{3}$ Ezt kimeríti akár a nagyon alacsony fokú gondatlanság is.
} 
A közérdek-magánérdek vita már a XIX. század végén sarkos következtetések levonását eredményezte az angol jogban. Mivel a vasúttársaságok parlamenti engedéllyel folytathatták csak tevékenységüket, a zavaró hatást elszenvedő földtulajdonosok számára eleve kizárt volt a zavarásra alapított igényérvényesítés (nuisanceclaims). Ezzel ugyanis egy magánszemély lényegében a parlament engedélyét torpedózhatta volna meg, és saját maga érhette volna el az állam által már jogszerünek minősített tevékenység jogellenessé nyilvánítását. Mivel a pályák építése érdekében folytatott kisajátítások a földárak emelkedését vonták maguk után, általánosan elfogadott érvelés volt, hogy a kártérítési felelősség elismerésével nem kell tovább erősíteni a tulajdonosokat megillető jogokat, mindenekelőtt a kisajátítási kártalanítás összegén felül újabb pénzösszeghez ne juthassanak. Azok a tulajdonosok, akiknek ingatlanja a vasúti sínekhez közel feküdt, vállalták a károkozás kockázatát. Ebből eredt az a megközelítés, miszerint vétkesség igazolása nélkül nem jár kártérítés még a gőzmozdony által okozott tüzben megsemmisült terményért sem. 1905-ben a Railway Fire Act azonban gyökeres változást hozott. Az objektív felelősség gondolatát megelőzve egy vétkesség nélküli átalánykompenzációt dolgozott ki. A mozdony szikrája által előidézett tüzekben elszenvedett károk kompenzálására kárátalány jellegü kompenzációt írt elő. A kompenzációra való jogosultsághoz nem volt szükséges a vasúttársaság vétkességének a bizonyítása, így az esetek döntő többségében a peres eljárások is elkerülhetők voltak. Ez a minimál kárátalány persze nem zárta ki, hogy az ezt meghaladó károkat a károsult a vétkesség bizonyítása mellet kártérítési perben követelje, azonban a gyakorlatban drámaian csökkent az erre alapított igényérvényesítések száma. Ez a megoldás fontos elemmel gazdagította a felelősségi jogot, hiszen napjainkban is visszaköszön például az Európai Uniós jogalkotás szintjén rendezett légitársaságok felelősségénél. ${ }^{4}$

\section{Jogpolitikai célok és eszközök megjelenése a kártérítési jogban}

A technológiai fejlődés generálta, majd a jogalkotás politikai céloktól vezérelt hatásait bemutató kártérítési esetkörök között az egyik legfelkavaróbb a XX. század második felének meghatározó „,csoda ásványa”, az azbeszt által okozott egészségkárosodásokra alapított kárigények problémája volt. ${ }^{5} \mathrm{Az}$ azbeszt sajátossága, hogy nem egyetlen tevékenység keretében vált népszerüvé, hanem több ezer termék készítésénél felhasználták, így valódi tömegek kerültek kapcsolatba vele, akár a gyártási folyamatban résztvevő munkásként, akár a végtermék felhasználójaként. Az azbeszt egészségügyi kockázata abban rejlik, hogy az ásvány porának belélegzése egymástól nagyon különböző szindrómák kialakulását eredményezheti: van, hogy évekig lappangó, apró elváltozásokat okoz az emberi szervezetben, és van, amikor gyors halálhoz vezet. Az azbeszt egészségre ártalmas természetével már viszonylag korán foglalkozott az orvostudomány, ugyanis 1906-ból már vannak feljegyzések, miszerint a Francia Gyárfelügyelet rámutatott arra a tényre, hogy az azbeszttel dolgozók tüdejében komoly patologikus elváltozások keletkeztek. ${ }^{6}$ 1909-ben egy olasz királyi rendelet már megtiltotta, illetve bizonyos feltételek közé szorította a gyermekek és a nők azbesztet felhasználó gyárakban való foglalkoztatását. ${ }^{7}$ Az első jogszabály, amely már az azbeszt kontrollálása érdekében született, a brit azbeszt ipar szabályozására elfogadott rendelet volt 1931-ben, amely megkövetelte, hogy a gyártók megfelelő szellőző

\footnotetext{
${ }^{4}$ 261/2004/EK rendelet a visszautasított beszállás és légijáratok törlése vagy hosszú késése esetén az utasoknak nyújtandó kártalanítás és segítség közös szabályainak megállapításáról.

5 TweEDALE, Geoffrey, MagicMineraltoKillerDust: Turner and Newall and theAsbestosHazard, Oxford University Press, 2000. 5.

6 Martin-CASAls, Miquel, The Development of LiabilityinRelationtoTechnologicalChange, Cambridge University Press, 2010. 19-20.

${ }^{7}$ FAVILLI, Chiara, TechnologicalChangeinItaly, In: MARTIN-CASALS, i.m., 213.
} 
berendezésekkel szereljék fel gyáraikat. $^{8}$

$\mathrm{Az}$ azbeszt okozta egészségkárosodásokra alapított igények sokkal nagyobb számban jelentek meg az Egyesült Államokban, mint Európában. Ennek magyarázata pedig éppen a közjogi rendszer sajátosságaiban keresendő. Míg az európai államok döntő többségében a társadalombiztosítás keretei között az orvosi kezelés költségei megtérültek, addig az USA-ban ilyen szociális biztosítási rendszer hiányában a károsultak kényszerültek a kezelési költségeket viselni. A szabályozás is másképpen reagált az azbeszt keresetekre. Németországban és Spanyolországban például a társadalombiztosítási jogszabályok egyenesen kizárták annak lehetőségét, hogy kártérítési keresettel is éljen a sérelmet szenvedett fél, míg Olaszországban és az Egyesült Királyságban a kártérítési keresetek voltak népszerübbek, hiszen a költségek teljes megtérülésére csak peres úton volt lehetőség. Franciaországban egy vétkességet nélkülöző kompenzációs rendszert vezettek be a tömeges igények kezelésére, mely ugyan nem zárta ki, hogy a károsult a kompenzáción felül kártérítési perben is érvényesíthesse igényét, azonban erre csak rendkívül ritkán került sor. Általánosságban elmondható, hogy az európai államokban a kártérítés jellemzően csak másodlagos szerepet játszott az azbeszt okozta károk megtérülésében. ${ }^{9}$ Németországban az 1884-ben elfogadott balesetbiztosítási törvény a munkáltatókat kivonta a kártérítési felelősség hatóköréből, és 1925-ben a biztosítási konstrukció minden foglalkozási megbetegedésre kiterjesztésre került.

$\mathrm{Az}$ azbeszt perek megmutatták, hogy a technológiai fejlődés által bevezetett új megoldásokban rejlő veszélyek nagyon eltérő reakciókra késztették az európai jogokat. Az objektív felelősség bár nagyon evidens megoldásnak tünhet ezekben a helyzetekben, azonban számos jogpolitikai döntés is meghúzódhat az új kockázatok kezelése mögött. Az azbeszt esetében látható, hogy bár nagyon sokáig engedte a jogalkotó az anyag használatát, még azt követően is, hogy köztudomású volt annak egészégre ártalmas volta, a megbetegedett személyek által elszenvedett sérelmek megtérítését nem tisztán a kártérítés rendszerében oldotta meg. Valódi kavalkád, ahogyan a biztosítási konstrukciók, a társadalombiztosítási modellek, a vétkességet vélelmező felelősségi rendszerek keveredtek egymással. A kártérítési jog és általában a polgári jogi felelősség láthatóan átpolitizált területté vált a XX. századra, melynek következtében a korábbi eszmék ${ }^{10}$ felpuhultak, és helyüket bizonyos felelősségi alakzatok esetében új megfontolások vették át.

\section{A kártérítés mint a hatalom eszköze}

A kártérítési jog legújabb kori fejlődésében tagadhatatlanul nagy jelentőséget kapnak a jogpolitikai megfontolások, és a korábban a károkozó rossz cselekvési választásának szankcionálása, a károsultat ért veszteség reparálása funkciókat jelentősen megbonyolították azok a jogpolitikai célok és eszmék, melyek napjainkban is éreztetik hatásukat. Marshall Shapo amerikai jogtudós már 1970-ben megállapította, hogy a kártérítési jog a hatalom újabb eszköze dominanciájának és akaratának kinyilvánítására. ${ }^{11}$ Még ha ennyire kiélezettnek és alkotmányjogi kérdéseket is felvetőnek nem látjuk a problémát, mindenképpen egyet kell értenünk azzal a megállapítással, mely már nem a kárkötelemben érintett jogalanyok szemszögéböl, hanem a köz vagy ha úgy tetszik az állam céljainak elérése érdekében avatkozott be a kártérítési jog fejlödésének folyamatába. Ennek az intervenciónak a legnyilvánvalóbb bizonyítéka a számos új, jellemzően objektív alapokra helyezett felelősségi alakzat megszületése, mely általában egy új technológia bevezetésével áll kapcsolatban.

\footnotetext{
${ }^{8}$ Morgan, Jonathan, TechnologicalChangein England and Wales, In: MARTIN-CASALS, i.m., 67.

${ }^{9}$ MARTIN-CASALS, i.m., 25.

${ }^{10}$ Vétkesség primátusából adódó prevenció, károsult érdekeit középpontba helyező reparáció.

${ }^{11}$ SHAPO, Marshall, ChangingFrontiersinTorts: Vistasforthe '70s, 22 Stanford Law Review, 1970. 330.
} 
Az objektív felelősségi alakzatok elterjedése mellett a másik, a polgári jogi felelősség klasszikus célkitüzéseit lerontó tényező a korábban már említett biztosítási konstrukciók elterjedése, elsősorban a kötelező felelősségbiztosítások megnövekedett jelentőségén keresztül. Néhányan a kártérítési jogot éppen ezen tényezők miatt már tisztán közgazdasági megközelítésben látják, a kártelepítés társadalommérnöki hozzáállásával felépített jogterületként, mely közcélok megvalósulását szolgálja, a magánérdekek helyett. ${ }^{12}$

A kártérítési jog bizonyos értelemben erősen átpolitizált területté vált a XX. század második felében, és így magánjogi dominanciáját megtépázták közjogi célok. Shapo jogi realistaként azzal az egyszerüsítéssel élt, hogy a kártérítési jogot valójában közjogi területként azonosította. ${ }^{13}$ A kontinentális jogok közjog-magánjog dichotómiájára építő megközelítése és a két terület éles elkülönítése azonban egyre kevésbé tartható doktrína, hiszen a jogalkotás akár indirekt módon, egy alapvetően közjogi jellegü norma átírásával is képes új irányt adni egy terület kártérítési jogi szempontú értékelésének.

Ezt az állítást a magyar jogból vett példával is alá tudjuk támasztani. Az Eütv. ${ }^{14} 13$. §-ában részletezett tájékoztatáshoz való jog mint betegjog teljesen új irányt adott az egészségügyi szolgáltatók kártérítési felelősségére alapított pereknek, ugyanis az orvosi mühiba vizsgálatáról a hangsúlyt a tájékoztatás nem megfelelő voltára helyezte át. A változást ebben az esetben a társadalom attitüdjében bekövetkezett fordulat idézte elő, hiszen az igényüket érvényesítő felperesek számára könnyebb és egyszerübb hivatkozásnak tűnt a tájékoztatás elégtelenségét állítani, mintsem egy orvosszakértői kérdésként az ő bizonyítási kötelezettségük körébe tartozó mühibára alapítani kártérítési igényüket.

Nem állítjuk, hogy az állam jogpolitikai döntései minden esetben tudatosan hatnak a kártérítési jogra. A jogszabályalkotás folyamatába beiktatott hatástanulmányoknak azonban a fent bemutatott, több jogrendszerből szemezgető példák tükrében mindenképpen nagy szerepe kell, hogy legyen. Az állam döntései ugyanis a gazdaságot, a piacot nyilvánvalóan befolyásolják, de számos esetben a kártérítési jogra is befolyást gyakorolhatnak. A kártérítési jog pedig visszahat a piacra, hiszen a piaci szereplők szolgáltatásaik árazásánál a felelősség alapját adó kockázatokat is alaposan mérlegelik.

\footnotetext{
${ }^{12}$ GoldBerg, John C. P. - ZIPURSKy, Benjamin C., Seeing Tort Law fromtheInternalPoint of View: Holmes and Hart onLegalDuties, 75 Fordham Law Review, 2006. 1580.

${ }^{13}$ SHAPO, (1970), im., 335.

14 1997. évi CLIV. törvény az egészségügyröl.
} 